\title{
Ortopedi ve travmatoloji ameliyatlarında floroskopi kullanımı
}

\author{
Use of fluoroscopy in orthopaedics and traumatology operations
}

\author{
Mert Özcan
}

Trakya Üniversitesi Tıp Fakültesi, Ortopedi ve Travmatoloji Ana Bilim Dalı, Edirne

\begin{abstract}
Modern ortopedi ve travmatoloji alanındaki cerrahide floroskopi kullanımına sık sık başvurulmaktadır. Yapılan çalışmalar göstermiştir ki ortopedi ve travmatoloji uzmanı cerrahlar etkili ve güvenli floroskopi kullanımı konusunda yeterli bilgi ve beceriye sahip değildirler. Bu yazının amacı, ortopedi ve travmatoloji uzmanı cerrahları radyasyon konusunda bilgilendirmek; ameliyathanede cerrah, hasta ve diğer personeli radyasyonun zararlı etkilerinden korumak adına pratik ve güncel bilgiler sunmaktır.
\end{abstract}

Anahtar sözcükler: floroskopi; ameliyathane; radyasyon; ortopedi ve travmatoloji ameliyatları
Fluoroscopy is frequently used in modern orthopaedics and traumatology operations. Studies have shown that orthopaedics and traumatology surgeons do not have sufficient knowledge and skill to make use of fluoroscopy safely and effectively. The aim of this paper is to give basic knowledge on radiation for orthopaedics and traumatology surgeons, and provide up to date information in order to protect surgeons, besides patients and operating room staff from its harmful effects.

Key words: fluoroscopy; operating room; radiation; orthopaedics and traumatology operations
B irçok ortopedi ve travmatoloji uzmanı ameliyathane uygulamalarında sıklıkla floroskopi kullanmak durumunda kalmaktadır. Özellikle travma ameliyatlarında artık sıklıkla başvurulan daha az invaziv girişimler, floroskopi kullanılmasını gerektiren ameliyat sayılarını ve floroskopi süresini artırmıştır. Bunun yanında omurga cerrahisinde, pediatrik ortopedide, tümör cerrahisinde, el cerrahisinde ve zaman zaman da artroplasti ameliyatlarında floroskopiye ihtiyaç duyulmaktadır.

Bu kadar floroskopi ile iç içe yaşayan ortopedi ve travmatoloji uzmanları, radyasyona sıklıkla maruz kalmalarına rağmen ameliyathanede floroskopi kullanımı ve radyasyonun zararları hakkında yeterli bilgiye sahip değildirler. ${ }^{[1]}$ Floroskopi esansında etrafa X-ışınları saçılır. X-ışınları iyonlaşstırıcı radyasyon yayan zararlı ışınlardır ve hücre DNA'sına doğrudan ya da dolaylı yollarla zarar verir. Doğrudan etkide radyasyon enerjisi DNA molekülündeki kimyasal bağları kırarak, dolaylı etkide ise DNA etrafında su moleküllerini ışınsal bozunuma (radyoliz) uğratarak ve serbest radikaller oluşturarak zarar verir. ${ }^{[2]}$

İyonlaştırıcı radyasyon sıvı ve gazlarda iyonlaşmaya sebep olurken, katı cisimlerle etkileştiğinde etrafa ikincil radyasyon saçılmasına sebep olur. Bu ikincil radyasyon ameliyathanede hastaya çarpıp etrafa yayılan fotonlardır ve ortamda bulunanların maruz kaldığı radyasyon bu saçılan fotonlardan kaynaklanmaktadır. İkincil radyasyonun enerjisi düşüktür, vücudu penetre edemez ve vücut tarafından emilir. Bu ışınlar aslında vücut tarafından emilen bir tür enerjidir ve zamanla doku ve organlarda birikerek hasar oluşturur. ${ }^{[3,4]}$

Yapılan araştırmalar floroskopi kullanılan ameliyathanelerde çalışan personelin iyonize edici radyasyona karşı bilgi düzeylerinin düşük olduğunu göstermiş̧tir. Ayrıca personelin, direkt radyasyon ile saçılan radyasyon arasındaki farkı ve güvenlik prosedürlerini bilmedikleri gösterilmiştir. Ameliyathane çalışanlarının bu

- İletişim adresi: Prof. Dr. Mert Özcan, Trakya Üniversitesi Tıp Fakültesi, Ortopedi ve Travmatoloji Ana Bilim Dalı, Edirne

Tel: 0533 - 4144819 e-mail: mertozcan@trakya.edu.tr

- Geliş tarihi: 9 Ocak $2021 \quad$ Kabul tarihi: 21 Ocak 2021

ORCID iD: Mert Özcan, 0000-0002-2009-1881 


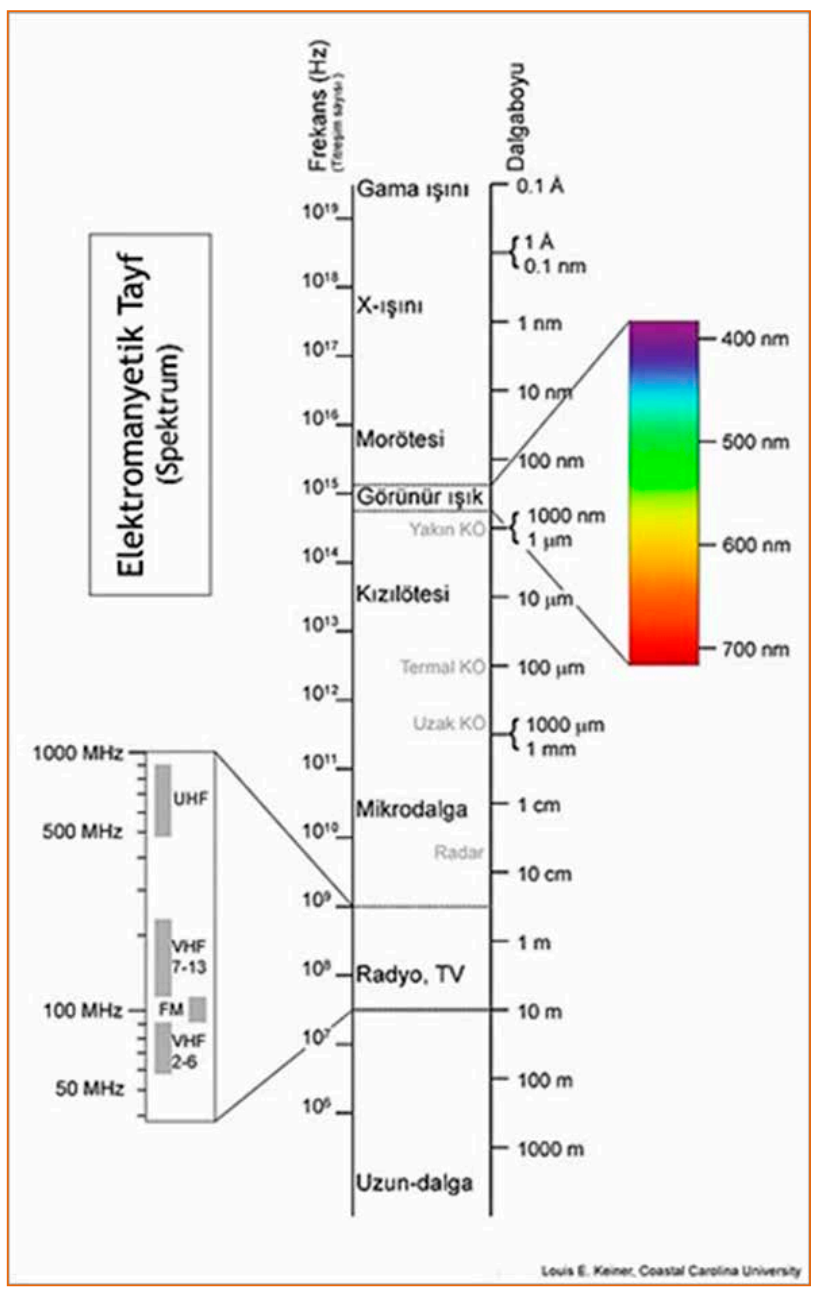

Şekil 1. Elektromanyetik tayf.

bilgi eksikliklerinden dolayı \%94'ünün tiroid koruma giymediği anlaşılmıştır. ${ }^{[1]}$ Günümüzde artık ameliyathanede güvenli radyasyon kullanımı ile ilgili eğitim programları düzenlenmektedir.

Bu yazıda amacımız radyasyonun fiziksel ve biyolojik özeliklerini tarif etmek, ortopedi ve travmatoloji alanındaki girişimlerde güvenli floroskopi kullanmanın önemini belirtmek ve hastaları, ameliyathane personelini ve cerrahları radyasyondan korumak için pratik bilgileri sunmaktır.

\section{RADYASYONUN FiZiKSEL ÖZELLIKLERi}

Radyasyon aslında tıpkı radyo dalgaları gibi elektromanyetik dalgalar şeklinde yayılan bir enerjidir. Elektromanyetik spektruma bakılacak olursa X-ışınlarının frekansının çok yüksek, dalga boyunun ise çok kısa olduğu görülür (Şekil 1). Bu kısa dalga

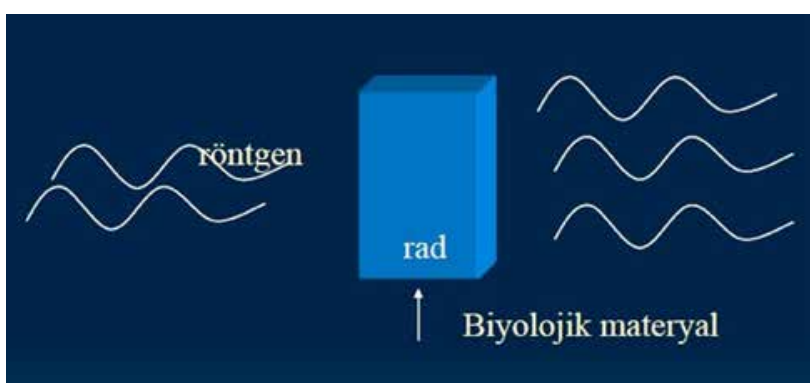

Şekil 2. Rad ve röntgen birimlerinin şematik anlatımı.

boylu yüksek enerjili ışınlar atomdan elektron kopartarak iyonlaştırma özelliğine sahiptir ve iyonlaştırıcı radyasyon olarak adlandırılır. Gama ışınları da X-ışınlarına benzer ancak iyonlaştırma özelliği daha fazladır ve dokular için daha tehlikelidir. Ancak tanısal amaçla kullanılan biyolojik cihazlarda gama ışınları kullanılmaz.

\section{ÖLÇÜM BIRIMLERi}

Temelde iki birim kullanılır. Röntgen, maruz kalınan dozu; rad (radiation absorbed dose) emilen dozu ifade eder. Ikisini birbirinden ayırt etmek gerekir. Kabaca izah etmek gerekirse, bir materyale girip arkasından çıkan ışınların akışına röntgen denir. Materyal tarafından emilen doz da rad'dır (Şekil 2). Biyolojik dokularda absorpsiyonu tanımlayan ise rem'dir. Rem yani biyolojik doz sadece rad'a bağlı olmayıp, lineer enerji transferine, doku içerisindeki dozun dağılımına, verilen doz miktarına ve dozun verilme sayısına bağlıdır. Sonuç olarak, biyolojik eşdeğer doz sievert $(\mathrm{sV})$ ile ölçülür ve emilen doz (rad) biyolojik etki ile tarif edilir; 1 rem, 0,01 sV'dir ve $1 \mathrm{sV}$ çok yüksek bir dozdur.

İyonlaştırıcı olmayan radyasyon hayatımızın bir parçasıdır. İzlediğimiz televizyon, kullandığımız elektronik aletler, radyo dalgaları hepsi bir enerji yayar, ancak bu radyasyon vücudumuza zararlı iyonlaştırıcı radyasyon değildir.

Aslında iyonlaştırıcı radyasyon da hayatımızın bir parçasıdır. Güneş ışınları, yediğimiz yiyecekler, etrafımızdaki birçok şey radyasyon yayar ve biz sürekli iyonlaştırıcı radyasyona maruz kalırız. Örneğin yüksek irtifa uçuşlarında saatte 0,001-0,01 mSv (millisievert) iyonlaştırıcı radyasyona, normal şartlarda yıl içerisinde ortalama 0,25 mSv iyonlaştırııı radyasyona maruz kalırız.

Tıbbi uygulamalarda ise ortamda daha yüksek dozlarda radyasyon vardır. Örneğin bir posterior-anterior (arka-ön) akciğer grafisinde ortalama $0,02 \mathrm{mSv}$ 
radyasyona maruz kalınırken, kafa grafisinde bu doz 0,1 mSv olur ki bu doz 5 akciğer grafisine eşittir. Lomber grafide bu doz 75 akciğer grafisine, batın bilgisayarlı tomografisinde (BT) 300, BT anjiyoda ise 850 akciğer grafisine eşit doza maruz kalınır (Tablo 1). Neyse ki floroskopi uygulamaları esnasında bu dozlar çok daha düşüktür. Özellikle ekstremite grafisi çekilirken doz daha düşük olur, ancak vertebra gibi daha kalın vücut dokuları incelenirken dozlar yine fazlalaşır. Bu nedenle omurga cerrahları daha fazla risk altındadır (Tablo 2). ${ }^{[5]}$

Şayet nükleer kazalar gibi rastlantısal olarak 0,5-1 Sv radyasyon dozu gibi çok yüksek dozlara anlık olarak maruz kalırsak radyasyon hastalığına yakalanırız ve bu, vücutta akut veya ileriye yönelik ciddi hasarlar bırakabilir. Rastlantısal olarak 1 Sv'den fazla doza maruz kalmak hayatla bağdaşmaz.

Radyoterapi esnasında da çok yüksek dozlar kullanılır (kanserin türüne göre 60000 mSv'ye kadar çıkabilir), ancak bu doz sadece hedef organa yönlendirilirken diğer dokular korunur. ${ }^{[5]}$

Tablo 1. Tıbbi uygulamalar ve maruz kalınan radyasyon miktarı

\begin{tabular}{lcc}
\hline Tıbbi uygulamalar & Uygulanan doz & PAAC* oranı \\
\hline PAAC & $0,02 \mathrm{mSv}$ & 1 \\
Kafa grafisi & $0,1 \mathrm{mSv}$ & 5 \\
Lomber AP** & $1,5 \mathrm{mSv}$ & 75 \\
Baryumlu Gl*** & $8 \mathrm{mSv}$ & 300 \\
Batın BT*** & $8 \mathrm{mSv}$ & 300 \\
BT anjiyo & $13 \mathrm{mSv}$ & 850 \\
\hline *Verilen doz ile kaç PAAC (posterior anterior akciğer) grafisi çekilebileceği. \\
** AP, anterior posterior. \\
** Gl, gastrointestinal. \\
*** BT, bilgisayarlı tomografi.
\end{tabular}

Tablo 2. Floroskopi uygulamaları ve maruz kalınan radyasyon miktarı

\begin{tabular}{lcc}
\hline Floroskopik uygulama & Uygulanan doz & PAAC* oranı \\
\hline El & 0,001 & 0,05 \\
Diz & 0,005 & 0,25 \\
Omuz & 0,01 & 0,5 \\
Pelvis & 0,6 & 30 \\
Kalça & 0,7 & 35 \\
Lomber & 1,5 & 75 \\
\hline * Verilen doz ile kaç PAAC (posterior anterior akciğer) grafisi çekilebileceği.
\end{tabular}

\section{RADYASYONUN BIYOLOJiK ÖZELLIKLERi}

Radyasyona maruz kalmak vücutta iki tür etki yaratır. Bunlardan birincisi somatik (deterministik) etkidir. $\mathrm{Bu}$ doza bağımlı bir durumdur ve rastlantısal olarak akut yüksek doza (0,5-1 Sv) maruz vücutta ciddi hasar bırakabilir (radyasyon hastalı̆̆ı). Eğer kişi radyasyon hastalı̆̆ının akut etkilerinden kurtulabilirse, gecikmiş etkiler zamanla ortaya çıkmaya başlar. Bunlar arasında lösemi, tiroid kanseri veya radyasyon kataraktı sayılabilir. Bu etkide, belirli bir eşik değer altında radyasyon ile ilgili sorunlar yaşanmaz. Bu biyolojik etki tek bir yüksek doza maruz kalma sonucu oluşur.

İkinci etki ise stokastik (kronik) etkidir. Buna birikmiş doz etkisi veya kronik etki de denir ve eşik değeri yoktur; az veya çok, radyasyona sürekli maruz kalan kişilerde görülebilir. Radyasyona bağlı kanserler bunlara iyi bir örnektir. Teratojenik etki, $10 \mathrm{mSv}$ sonrası kesindir ve gebeliğin sonlandırılması önerilir. Uluslararası radyasyon korunma komitesinin (ICRP) kurallarına göre radyasyondan korunma prensipleri; gerekçelendirme, uygulamada etkinlik (optimizasyon) ve doz sınırlama olarak tarif edilmiştir. Gerekçelendirme; radyasyonun zararlı etkileri göz önünde bulundurularak, net bir yarar sağlamayan hiçbir radyasyon uygulamasına izin verilmemesidir. Optimizasyon ise tedavi amaçlı ışınlamalar hariç, radyasyona maruz kalmayı gerektiren uygulamalarda mümkün olan en düşük dozun alınmasını sağlamaktır. Buna ALARA (As Low As Reasonably Achievable - mümkün olan en düşük doz) prensibi denilmektedir. Doz sınırlaması olarak da radyasyona maruz kalan tıbbi personel için bir doz limiti yoktur. Mümkün olan en az radyasyon teması gereklidir. ICRP'nin belirlediği bazı sınırlamalar vardır. Meslekle ilgili maruziyet ortalamaya vurulduğunda yılda 20 mSv'yi geçmemelidir ve bir yılda alınabilecek maksimum doz 50 mSv olabilir. ${ }^{[5]}$ Kabaca tarif edilecek olursa, hızlı ve çok sayıda bölünmeye maruz kalan dokular radyasyona daha duyarlı olurken, bölünme hızı yavaş veya sabit olan dokular radyasyona daha dirençlidir.

\section{AMELIYATHANE EKIBININ VE CERRAHIN RADYASYONDAN KORUNMASI}

Günümüz modern ortopedi ve travmatoloji alanındaki cerrahi uygulamalarda floroskopinin yeri çok fazladır. Her geçen gün artan daha az invaziv uygulamalar, floroskopi kullanım sıklığını artırmıştır. Şekilde, ameliyathanede kullanılan modern floroskopi cihazı ve bölümleri gösterilmektedir (Şekil 3).

Ameliyathanede çalışan personelin floroskopiden korunma prensiplerini dört başlık altında toplayabiliriz: Mesafe ve pozisyon (distance ' $D$ '), süre (exposure ' $E$ '), bariyer kullanımı (barrier ' $B$ ') ve cihazın teknik 


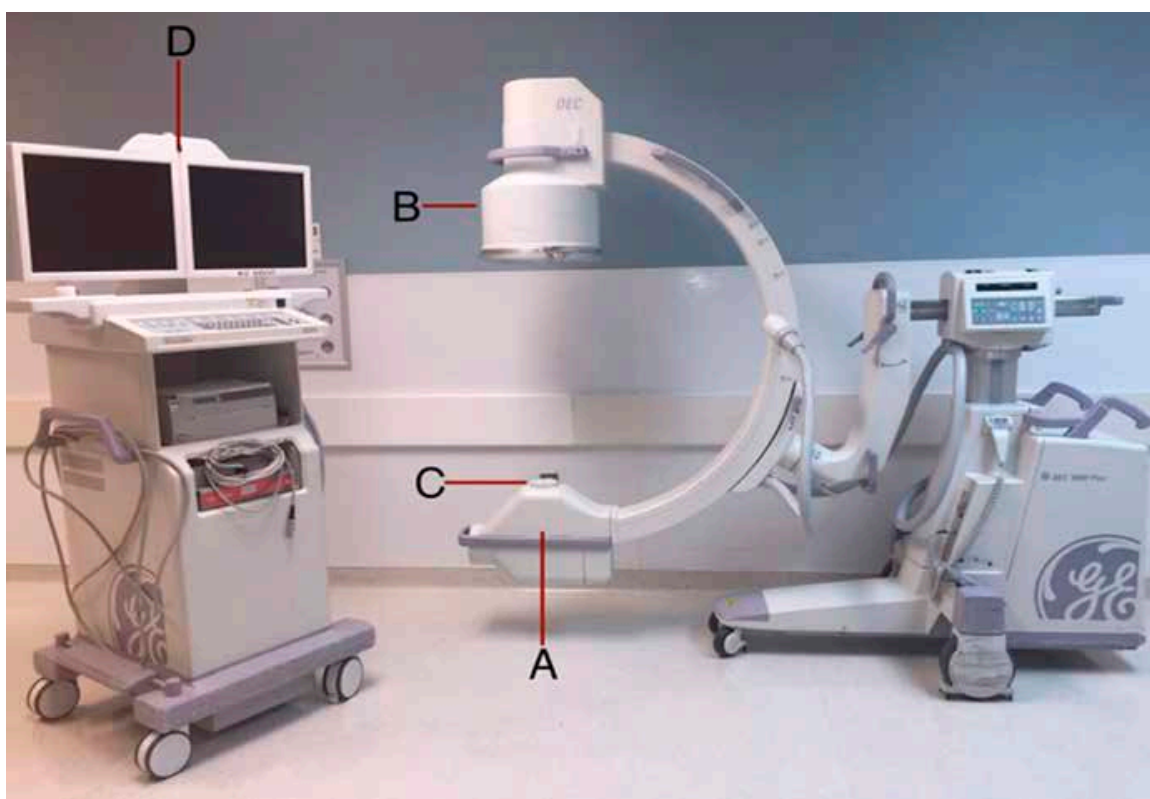

Şekil 3. Floroskopi cihazının görünümü (A, X-ışını tüpü; $B$, görüntü alıcı; $C$, kolimatör; $D$, ekran).

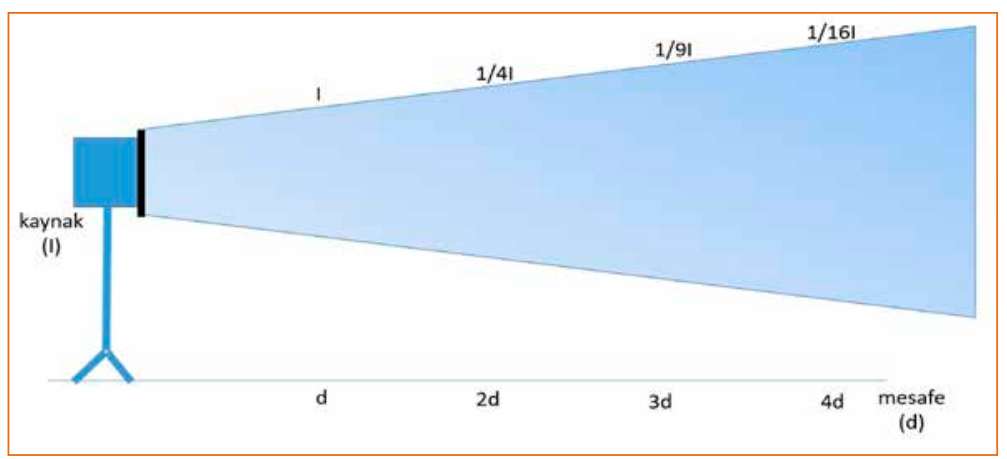

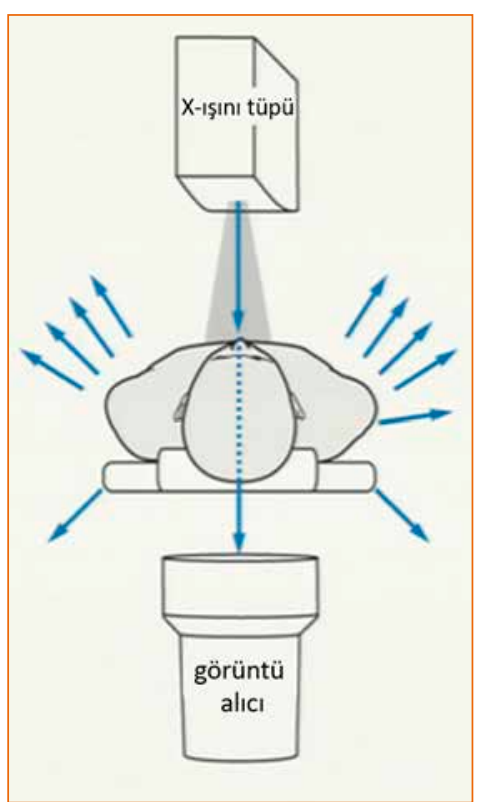

Şekil 4. Floroskopi cihazından fırlatılan fotonların ameliyathanede izledikleri yol.

Şekil 5. Size ulaşan foton miktarı mesafenin karesi ile ters orantılıdır.

özellikleri (technique 'T'). Bu dört başlık baş harfleri birleştirilerek DEBT prensipleri adı ile tanımlanmaktadır. Bu dört prensibi tek tek inceleyecek olursak:

\section{A- Mesafe ve Floroskopinin Yeri}

Bu konuya başlamadan önce floroskopiden çıkan fotonların nasıl bir yol izlediği ve hangilerinin bize zarar verdiğini anlamamız gerekiyor. X-ışını tüpünden 1000 tane foton fırlatıldığını hayal edelim (Şekil 4). Bu 1000 fotondan yaklaşık 100-200 tanesi hastaya çarparak etrafa saçılır, 20 tanesi görüntü alıcıya ulaşarak görüntüyü oluşturur, geriye kalanlar ise hasta tarafından emilir (hastanın aldığı radyasyon dozu). İşte bu etrafa saçılan fotonlar ameliyathane personeli için zararlı olan ışımadır. Floroskopi esnasında cerrah ve ameliyathane personeli için ana radyasyon kaynağı bu saçılan fotonlardır ve bu saçılma her zaman tüp tarafına doğru olur. Mesafe ve floroskopinin yerleştirilmesi ile ilgili dört basit kural vardır ve bunlara uyulması alınacak doz miktarını neredeyse sıfıra indirir.

\section{1- Mesafe}

Mesafe uyulması en kolay ve radyasyondan korunmada en etkili yöntemdir. Size ulaşan radyasyon mesafenin karesi ile ters orantılıdır (Şekil 5). Bir örnek verilecek olursa; floroskopiden 2 metre uzağa geri çekilirsek alacağımız doz 4 kat, 4 metre geri çekilirsek 16 kat azalacaktır. Teorik olarak 2 metreden sonra alınan dozun çok az olduğu ve ihmal edilebileceği düşünülmektedir. Bu nedenle, ışın gönderilirken mümkünse herkes hasta ve tüpten 2 metre uzağa çekilmelidir.

\section{2- Floroskopinin yeri}

Bizim için zararlı fotonların etrafa saçılan fotonlar olduğunu bildiğimiz için, saçılan foton sayısını en aza 


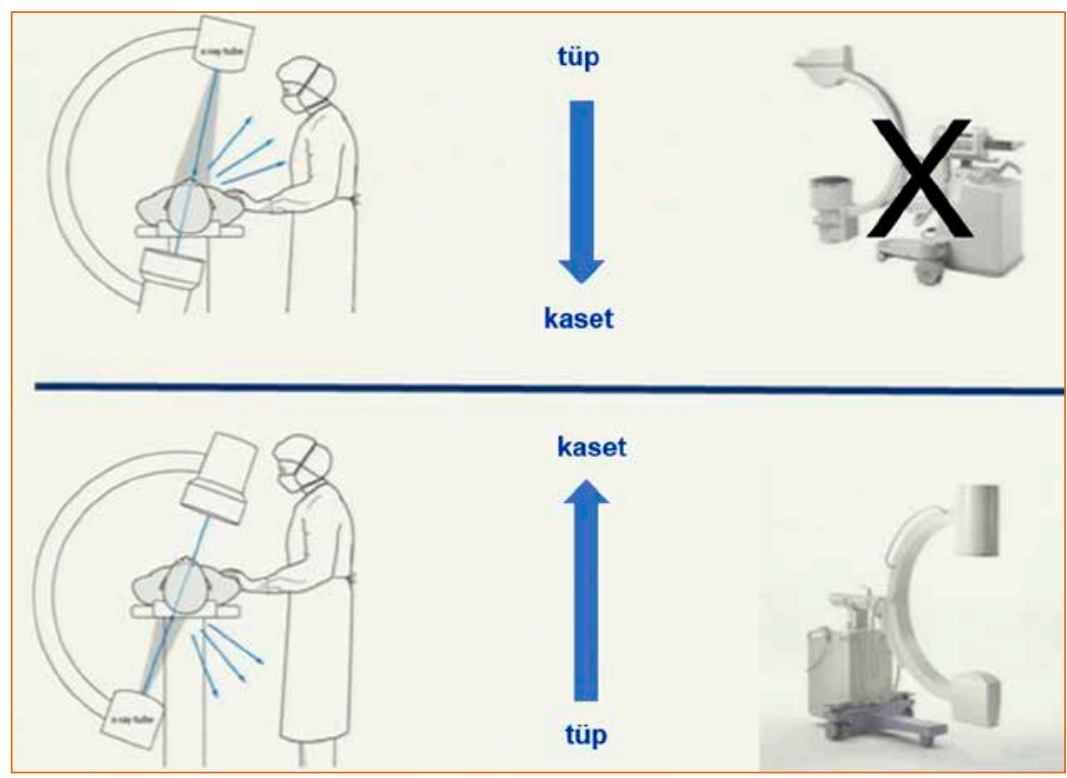

Şekil 6. Floroskopinin yeri. Saçılan fotonlardan korunmak için X-ışını tüpü masanın altında yer almalıdır.

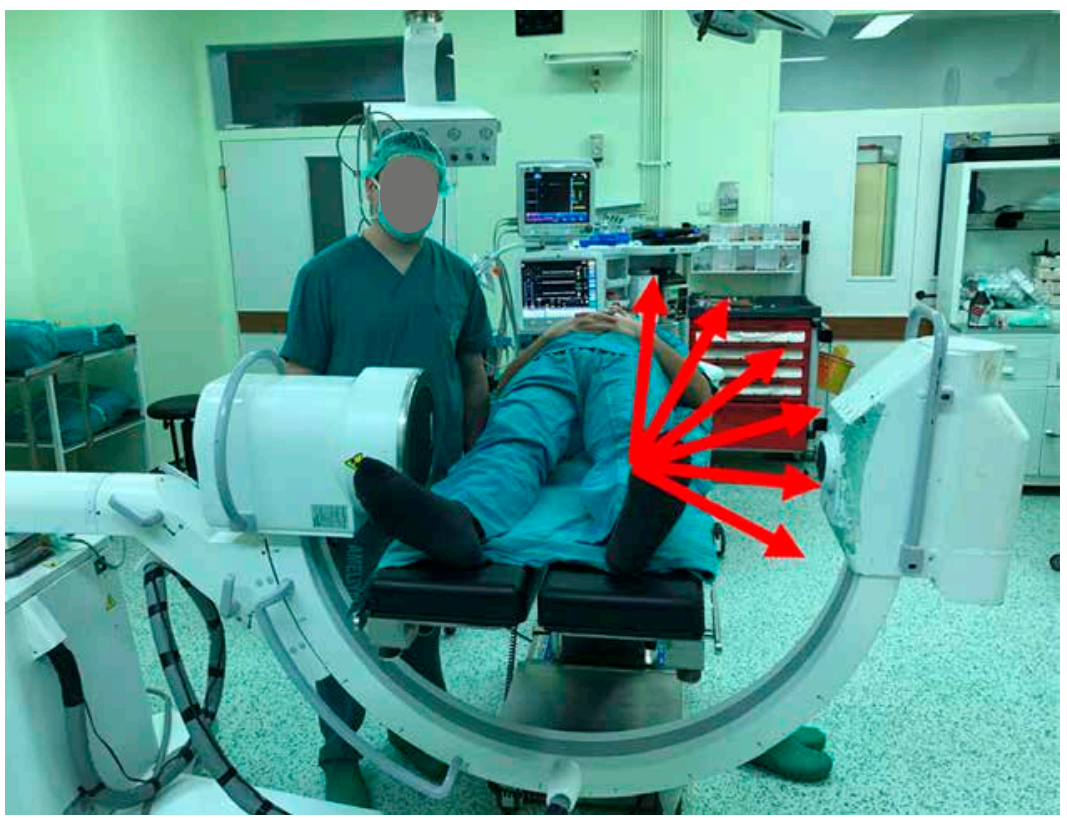

Şekil 7. Yan görüntü alırken cerrah X-ışını tüpünün karşısında yer almalıdır.

indirmek floroskopinin uygun şekilde konumlandırılması ve bizim floroskopinin doğru tarafında durmamız ile mümkündür. Skopinin ışın gönderen bölümü yani X-ışını tüpü mutlaka masanın altında olmalıdır. Bu şekilde saçılan fotonlar masaya çarpıp yere doğru saçılacaktır ve bize ulaşan foton sayısı azalacaktır (Şekil 6). Pedikül vidası yerleştiren omurga cerrahlarının maruz kaldığı radyasyon miktarını belirlemek için yapılan bir çalışmada, çekim esnasında tüp tarafında kalmanın riski 10-12 kat artırdığı hesaplanmıştır. ${ }^{[6]}$

\section{3- Cerrahın pozisyonu}

Omurga için lateral grafi çekerken olduğu gibi, şayet tüp masa altında konumlandırılamayacaksa (Şekil 7), cerrah mutlaka tüpün karşısında konumlanmalıdır. Bu çelişkili bir durum gibi görünebilir, ışınların karşısında yer almak daha fazla fotona maruz kalabileceğimiz izlenimi doğurabilir. Ancak cerrah için zararlı fotonların tüpten çıkanlar değil, hastadan saçılanlar olduğu unutulmamalıdır. Saçılan radyasyon, Şekil 7'de de görülebileceği gibi tüp tarafında daha çok olmaktadır. 


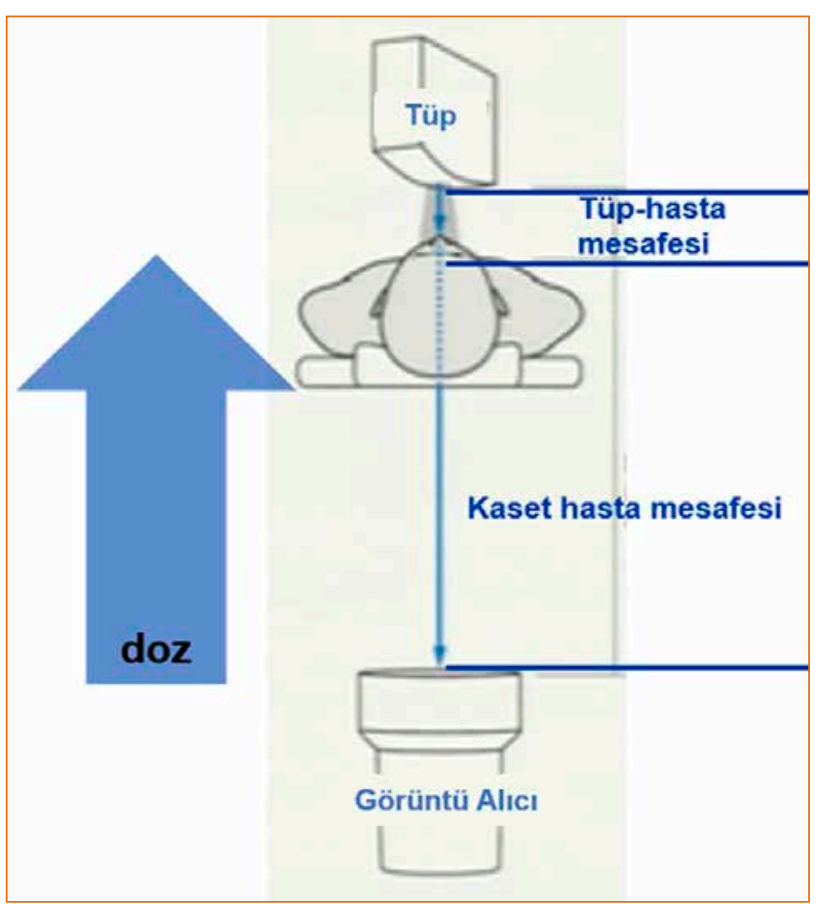

Şekil 8. Tüp-hasta mesafesi azaldıkça etrafa saçılan foton sayısı artar.

Bu durumda, mümkünse tüpten uzaklaşmak en iyi korunma yöntemidir. Eğer hastadan uzaklaşamıyorsak, tüpün karşısında pozisyon almak, maruz kalacağımız radyasyon dozunu 10 kata kadar azaltmaktadır. ${ }^{[6]}$

\section{4- Tüp hasta mesafesi}

Görüntü alınırken tüpün hastaya yakın olması hem hastanın alacağı dozu hem de etrafa saçılan foton sayısını artırmaktadır. Görüntü alırken, hastayı tüpten mümkün olan en uzak mesafede konumlandırmalıyız (Şekil 8).

Ameliyathanede maruz kalınan radyasyon miktarı yıllar içerisinde birçok çalışmanın konusu olmuştur. Cerrahi esnasında kimin daha çok radyasyona maruz kaldığının araştırıldığı bir çalışmada, 3 ay boyunca 107 ameliyatta gözlem yapılmış ve cerrahın floroskopiden çoğunlukla $90 \mathrm{~cm}$ 'den daha uzak durduğu, birinci asistanın hastaya en yakın mesafede durduğu tespit edilmiştir (ortalama $10 \mathrm{~cm}$ ). ${ }^{[7]}$ Buna bağlı doz ölçümü yapıldığında cerrahın açık kalan bölgelerinde ortalama 3 mrem (millirem), kurşun önlük altında ise sıfır radyasyona rastlanmıştır. Asistanda ise açıkta kalan bölgelerde 20 mrem radyasyona rastlanırken, önlük altında bile 7 mrem radyasyon ölçülmüştür. Bu çalışma mesafenin ne kadar etkin bir korunma yöntemi olduğunu göstermektedir.

\section{B- Süre}

Radyasyona maruz kalınan sürenin kısaltılması, alınacak radyasyon miktarını da azaltacaktır. Bunun için ameliyat öncesi planlama çok önemlidir. Skopinin yeri doğru belirlenmelidir; çekim yapılacak bölgenin mümkünse işaretlenmesi, tek seferde doğru görüntü alabilmek için önemlidir. Entegre lazer nişangâhı olan cihazlar bu konuda çok yararlıdır. Dinamik çekimlerden mutlak surette kaçınılmalıdır, hareketli görüntü çekmek ameliyathanede yapılacak en kötü harekettir ve bizi yüksek dozda radyasyona maruz bırakır.

Kanal içi çivilerin kilitlenmesi esnasında cerrahın tecrübesi ile alınan radyasyon dozunun karşılaştırıldığı 22 hastalık bir çalışmada, kıdemli cerrahların bu işi istatistiksel olarak anlamlı bir şekilde daha hızlı yaptıkları, dolayısıyla maruz kaldıkları radyasyon miktarının da özellikle ellerde istatistiksel olarak çok daha az olduğu gösterilmiştir. ${ }^{[8]}$ Bu durum, uzun süreli maruziyetin mesleğin ilk yıllarında daha büyük bir sorun olduğunu göstermektedir.

\section{C- Bariyer Kullanımı}

Bariyer kullanımın önemine geçmeden önce çekim esnasında hastanın alacağı doza etki eden faktörlerden de bahsetmek gerekir. Daha fazla miktarda radyasyon kullanılması gereken durumlarda bariyer kullanımının önemi bir kat daha artmaktadır. Hastanın maruz kalacağı dozu belirleyen en önemli faktör hastanın kütlesidir. Daha geniş yüzey alanına sahip kilolu hastalarda görüntü alabilmek için daha fazla doz verilir (Şekil 9). Yüzeysel alan arttıkça yüzeye (cilt) etki eden ve etrafa saçılan radyasyon miktarı artmaktadır. Böyle hastalarla çalışırken, daha uzakta durmak ve koruyucu ekipmanı eksiksizce kullanmak gerekir. Yine daha önce bahsedildiği üzere, tüp-hasta mesafesi artırılmalı ve mümkünse tüp masa altına yerleştirilmelidir.

Hangi vücut bölgelerinin daha duyarlı olduğundan yukarıda bahsedilmiştir. Hassas bölgeler mutlaka korunmalıdır. Bir de, çekim esnasında alanda kalan eller oldukça yüksek miktarda doğrudan radyasyona maruz kalmaktadır. Neyse ki bu bölgenin radyasyon duyarlılığı düşüktür. Yine de eller, özellikler el cerrahisinde oldukça risklidir ve korunmalıdır.

Göz de oldukça duyarlı bir doku olup, eğer hastayla yakın temasta kalacaksak mutlaka korunmalıdır. Zamanla gözlerde radyasyon kataraktı gelişebilmekte ve bu durum aşırı radyasyon yükünün ilk habercisi olabilmektedir.

Tiroid, radyasyona oldukça duyarlı bir organdır. Papiller karsinomun \%85'inin radyasyon kaynaklı olduğu bildirilmiştir. Tiroid koruyucu, her ameliyatta mutlaka kullanılmalıdır ki kullanılması en çok ihmal edilen bariyerdir. 

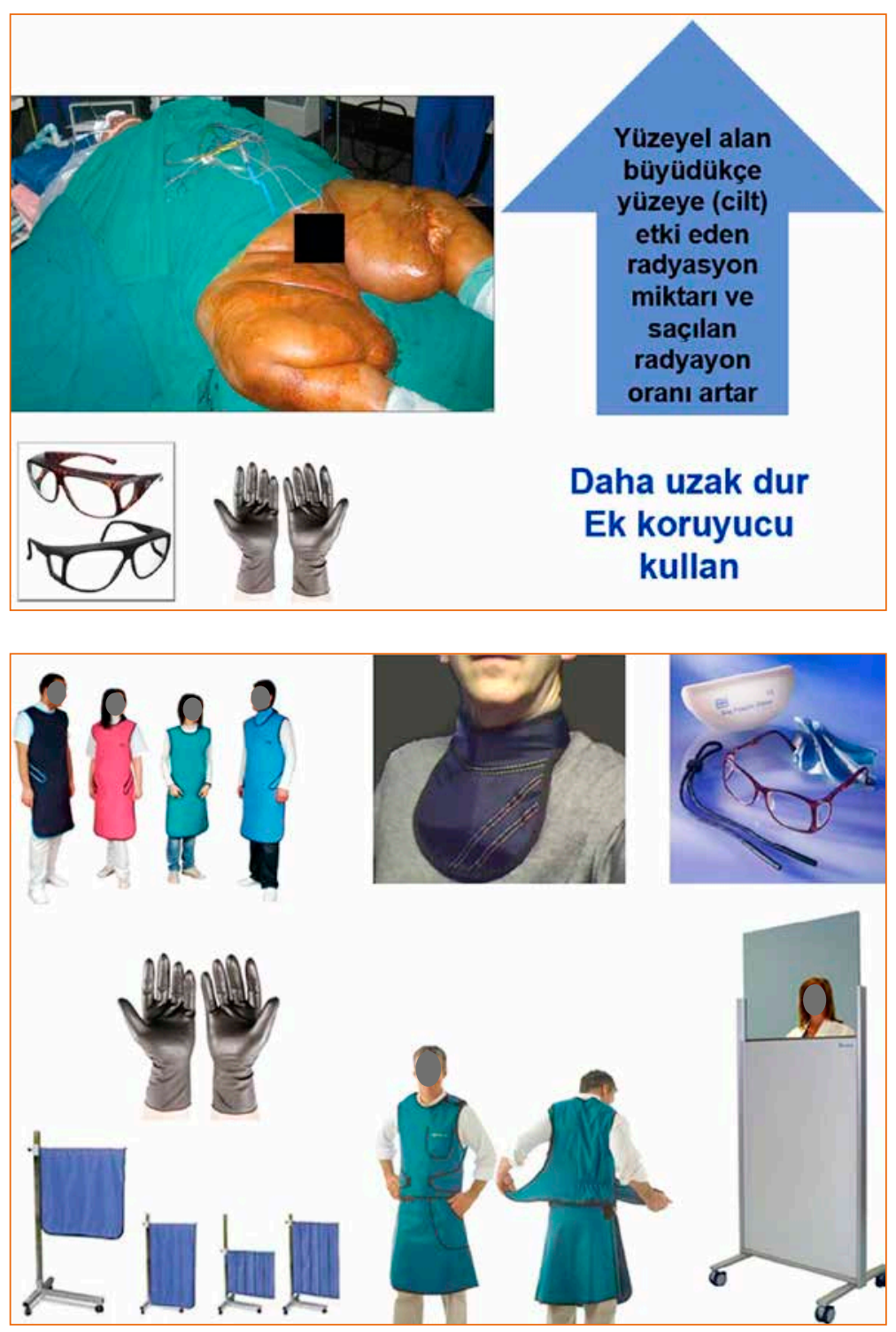

Şekil 9. Hastanın kütlesi ve yüzey alanı arttıkça, tüpten çıkan foton miktarı, dolayısıyla etrafa saçılan radyasyon miktarı artar.

Şekil 10. Ameliyathanede kullanılan çeşitli radyasyondan korunma bariyerleri.
Kullanılan bariyerler, kullanıldıkları bölgelere göre farklı oranlarda radyasyon maruziyetini engeller (Şekil 10). Kurşun kaplama (0,15 mm) gözlükler göze gelen radyasyon miktarını $\% 70$ azaltır. Tiroid koruma takıldığında maruziyetin 2,5 kat azaldığı bulunmuştur. Kurşun önlük kullanmak ise ön-arka planda 16 kat, lateral planda ise 4 kat korunmayı artırır. Kurşun alaşımla kaplı eldiven, kullanması zor (hantal ve ağır) olmakla beraber, kullanıldığı yere göre maruziyeti \%35'e kadar azaltabilmektedir. ${ }^{[6]}$

Pratik olarak, tüm bu koruyucular (Şekil 10) ameliyathanede bulunmalı ve floroskopi kullanılan her ameliyatta giyilmelidir. Bu koruyucu donanım rutin aralıklarla radyasyon kontrol komiteleri tarafindan kontrol edilmeli, hasarlı, kırık ve iş görmeyen malzemelerin yenileri ile değiştirilmesi gerekmektedir. Kullanıcılar, bu ekipmanın kolay deforme olduğunu, kırılabileceğini ve böylece etkinliğini yitirebileceğini mutlaka bilmeli ve uygun şekilde kullanmalıdır. Özellikle kurşun önlükler çıkartıldıktan sonra yerine asılmalı, etrafta bırakılmamalı ve sağa sola atılmamalıdır.

\section{D- Teknik (Teknoloji)}

Ameliyathanede kullanılan modern floroskopi cihazları son derece teknolojik cihazlar olup bu cihazların tüm özelliklerinin iyi bilinmesi, ameliyat esnasında maruz kalacağımız radyasyon dozunu belirgin şekilde azaltabilir. 


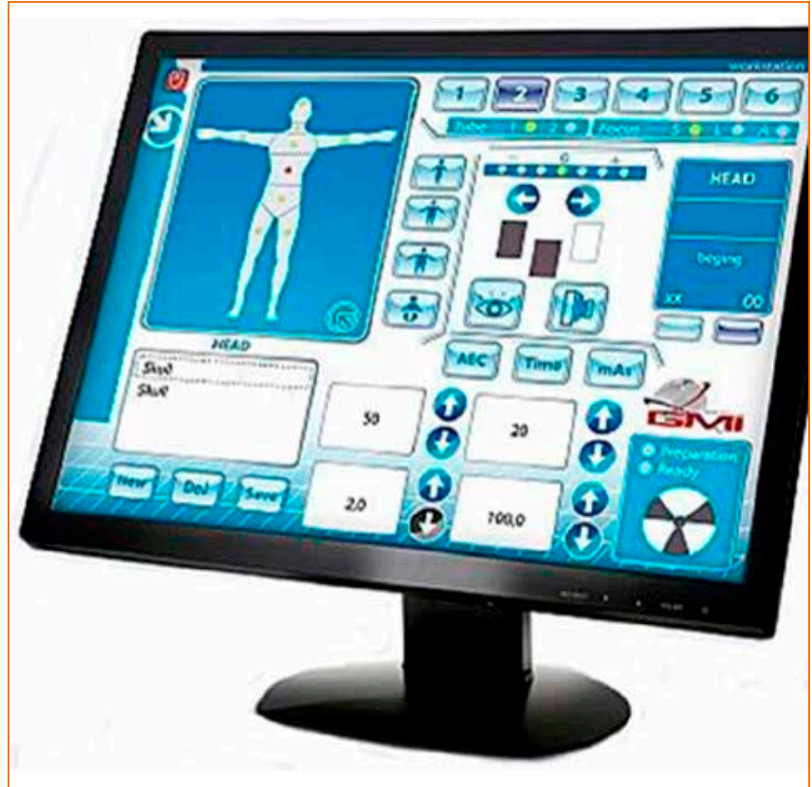

Şekil 11. Sanal bölge ayarı. Floroskopi cihazı en uygun dozda en iyi görüntüyü sağlamak için otomatik olarak programlanır.

Sanal bölge çekim ayarı ile (Şekil 11) hastanın hangi bölgesinde çalışılıyorsa bu alan seçilerek, cihazın uygun doz vermesi sağlanabilir. Yine, hastanın kütlesi ve yüzey alanı düşükse düşük doz ayarı kullanılarak maruz kalınan radyasyon miktarı azaltılabilir (Şekil 12).

Kolimatör (Şekil 13), genelde ne işe yaradığı bilinmeyen bir araçtır. Şayet görmek istediğimiz alan küçük bir alansa, kolimatör yardımı ile bu alana odaklanıp hem hastanın hem de ameliyathane çalışanlarının daha az doz almasını sağlayabiliriz. Kolimatör geniş̧liği ayarlanarak, ışınların yönü ve ne kadar geniş alana etki edeceği belirlenebilir.

Yine, modern cihazların görüntü belleği bulunmaktadır. Çekilen her görüntünün belleğe alınması, aynı planda görüntü almak istediğimizde bize ışın vermeden görüntüye ulaşabilme şansı verir. Bellekteki bu görüntüye ulaşılarak, yeni görüntüye ihtiyaç duymadan planlamalar yapılabilir.

Şayet entegre lazer nişangâhımız yoksa kendi koyacağımız işaretler ile de çekilen görüntü sayısını azaltabiliriz. Tek seferde istenilen alanın istenilen düzlemde görülebilmesi radyasyon maruziyetini çok azaltacaktır. Hastanın üzerine koyacağımız işaretler (Şekil 14) veya floroskopinin yerinin en iyi görüntü verdiği şekliyle yere işaretlenmesi, floroskopinin alana girip çıkarken doğru konumlanmasını sağlayacak ve gereksiz şutlamalardan kaçınılabilecektir (Şekil 14).

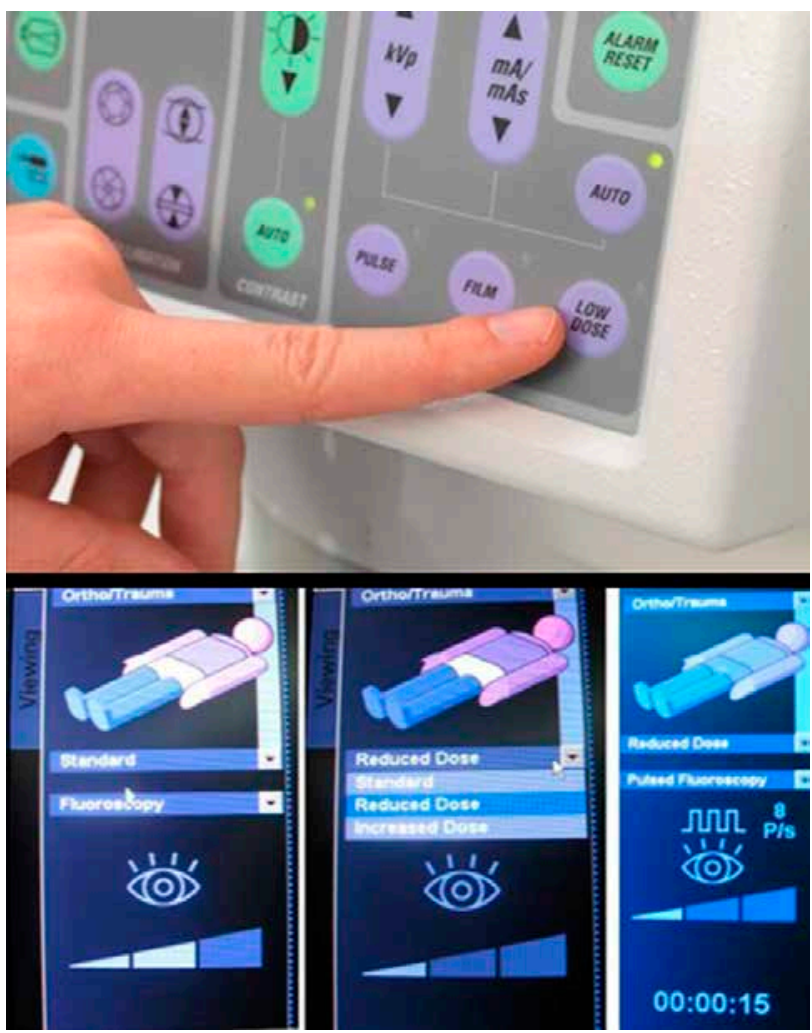

Şekil 12. Daha küçük kütleli hastalarda düşük doz tuşu kullanılarak radyasyon maruziyeti yarı yarıya azaltılabilir.

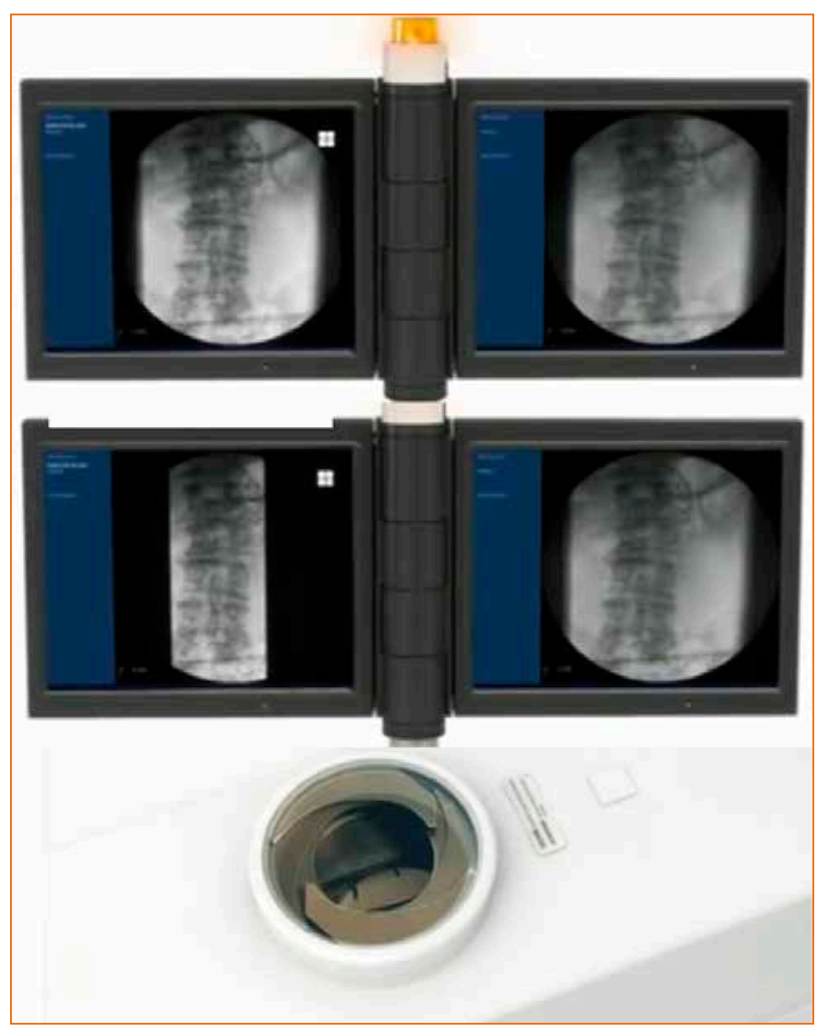

Şekil 13. Kolimatör kullanımı. X-ışını tüpünden çıkan foton miktarı kolimatör kullanılarak azaltılıp artırılabilir. 


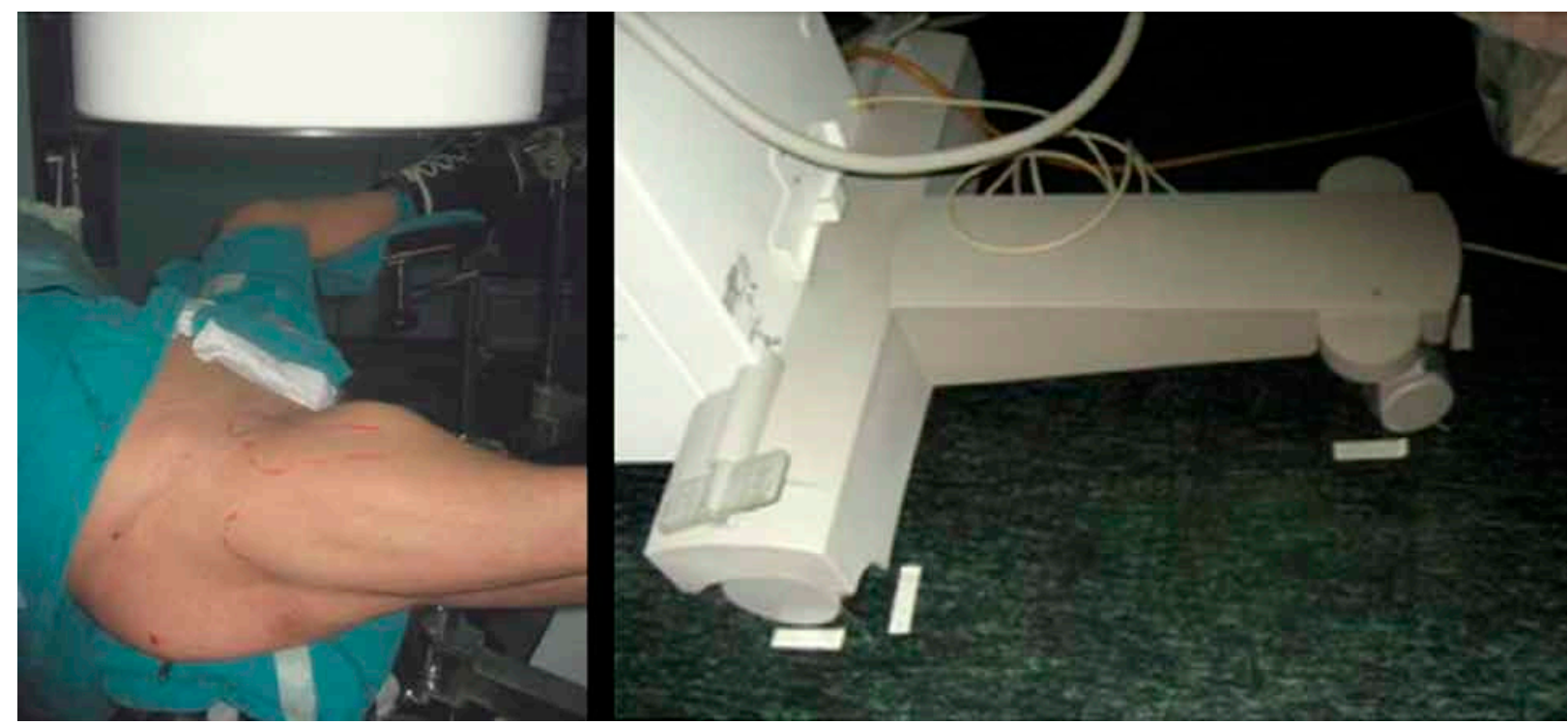

Şekil 14. Hastanın cildi üzerine veya ameliyathane zeminine koyulacak işaretler floroskopi kullanım sayısını azaltacaktır.

\section{SONUÇ}

Modern bir ortopedi ve travmatoloji uzmanı ameliyathanede radyasyonla çalışmak zorundadır. Bazı ameliyatlarda (omurga cerrahisi, pelvis cerrahisi) daha fazla radyasyona maruz kalınmaktadır. Bir cerrah olarak görevimiz, hastamızı, ameliyathane personelini ve kendimizi radyasyondan en etkin biçimde korumaktır. Bunun için ameliyat öncesi floroskopinin konumu ve alana nasıl girip çıkacağı ile ilgili planlamalar yapılmalı, hasta ve ameliyathane zeminine gerekli işaretler yerleştirilmelidir. Tüp, mümkünse her zaman masanın altında kalmalıdır. Unutulmamalıdır ki bizim için tehlikeli olan tüpten çıkan fotonlar değil, hastaya çarpıp etrafa saçılan fotonlardır. Bu nedenle, özellikle omurga cerrahisinde yan görüntü alırken tüpün karşı tarafına, yani görüntü alıcısına yakın durulmalıdır. Saçılan radyasyon, görüntü alıcının yanında en az olmaktadır. X-ışını tüpü hastadan mümkün olan en uzak pozisyonda tutulmalıdır. Saçılan radyasyon düşünülerek, sahadan mümkünse uzaklaşılmalıdır. Görüntü alınırken 2 metre uzaklaşmak yeterli olacaktır ve ameliyathaneden çıkmaya gerek yoktur. Koruyucu donanım sağlıklı bir şekilde muhafaza edilmeli ve istisnasız her ameliyatta mutlaka kullanılmalıdır (önlük, tiroid koruyucu). Çekim esnasında, eller hasta ile X-ışını tüpü arasında bulundurulmamalıdır. Eller ciddi risk altındadır ve korunmalıdır. Ameliyathanede kullandığımız cihazın teknik özellikleri iyi bilinmelidir. Bu, maruz kalınan dozu neredeyse yarı yarıya kadar düşürebilmektedir. Son olarak, ameliyathanede floroskopi kullanan bir radyoloji teknisyeninin mutlaka olması tavsiye edilmektedir.

\section{KAYNAKLAR}

1. Khan F, Ul-Abadin Z, Rauf S, Javed A. Awareness and attitudes amongst basic surgical trainees regarding radiation in orthopaedic trauma surgery. Biomed Imaging Interv J 2010;6(3):e25. Crossref

2. Yılmaz B, Çopuroğlu C, Tabakçığlu K, Pala FS, Özcan M, Çiftdemir M. Ameliyathanede maruz kalınan floroskopik radyasyon etkisinin biyolojik doz değerlendirmeleri. JAREM 2018;8(1):19-24. Crossref

3. Brenner DJ, Doll R, Goodhead DT, Hall EJ, Land CE, Little JB, Lubin JH, Preston DL, Preston RJ, Puskin JS, Ron E, Sachs RK, Samet JM, Setlow RB, Zaider M. Cancer risks attributable to low doses of ionizing radiation: assessing what we really know. Proc Natl Acad Sci U S A 2003;100(24):13761-6. Crossref

4. Akbar-Khanzadeh F, Jahangir-Blourchian M. Ultraviolet radiation exposure from UV-transilluminators. J Occup Environ Hyg 2005;2(10):493-6. Crossref

5. Coşkun i. Radyasyonun tıpta kullanımı. Anka Enstitüsü, 26/02/2018. http://ankaenstitusu.com/radyasyonun-tipta-kullanimi/

6. Rampersaud YR, Foley KT, Shen AC, Williams S, Solomito M. Radiation exposure to the spine surgeon during fluoroscopically assisted pedicle screw insertion. Spine (Phila Pa 1976)2000;25(20):2637-45. Crossref

7. Tasbas BA, Yagmurlu MF, Bayrakci K, Ucaner A, Heybeli M. Which one is at risk in intraoperative fluoroscopy? Assistant surgeon or orthopaedic surgeon? Arch Orthop Trauma Surg 2003;123(5):242-4. Crossref

8. Blattert TR, Fill UA, Kunz E, Panzer W, Weckbach A, Regulla DF. Skill dependence of radiation exposure for the orthopaedic surgeon during interlocking nailing of long-bone shaft fractures: a clinical study. Arch Orthop Trauma Surg 2004;124(10):659-64. Crossref 